\title{
Feeding on copepod fecal pellets: a new trophic role of dinoflagellates as detritivores
}

\author{
Louise K. Poulsen $^{1, *}$, Morten Moldrup ${ }^{2}$, Terje Berge ${ }^{3}$, Per Juel Hansen ${ }^{2}$ \\ ${ }^{1}$ Technical University of Denmark, Charlottenlund Castle, Jægersborg Allé 1, 2920 Charlottenlund, Denmark \\ ${ }^{2}$ Marine Biological Section, University of Copenhagen, Strandpromenaden 5, 3000 Helsingør, Denmark \\ ${ }^{3}$ Marine Biological Section, University of Copenhagen, Østre Farimagsgade 2D, 1353 Copenhagen $K_{r}$ Denmark
}

\begin{abstract}
Recent field studies indicate that dinoflagellates are key degraders of copepod fecal pellets. This study is the first to publish direct evidence of pellet grazing by dinoflagellates. Feeding and growth on copepod fecal pellets were studied for both heterotrophic (4 species) and mixotrophic dinoflagellates (3 species) using a combination of classic incubation experiments and video recordings of feeding behavior. Fecal pellets were produced by adult Acartia tonsa feeding on Rhodomonas salina. Two mixotrophic species (Karlodinium armiger, a gymnodinoid dinoflagellate, Gy1) and all heterotrophic dinoflagellates (Gyrodinium dominans, Gyrodinium spirale, Diplopsalis lenticula, Protoperidinium depressum) studied fed on fecal pellets. Using natural concentrations of dinoflagellates and copepod fecal pellets, average ingestion rates of 0.2 and 0.1 pellets cell ${ }^{-1} \mathrm{~d}^{-1}$ and clearance rates of between 0.2 and $0.3 \mathrm{ml} \mathrm{cell}^{-1} \mathrm{~d}^{-1}$ were obtained for G. spirale and P. depressum, respectively. Pellet feeding resulted in average growth rates of 0.69 and $0.08 \mathrm{~d}^{-1}$ with growth yields of 0.58 and 0.50 for G. spirale and P. depressum. Important factors for the grazing impact of the dinoflagellates on fecal pellets in this study were: dinoflagellate concentration, the dinoflagellate-to-pellet size ratio, the feeding mechanism, pellet food source, and pellet age. This study reveals a new trophic role for dinoflagellates as detritivores, and shows that large $(>20 \mu \mathrm{m})$ heterotrophic dinoflagellates alone can account for reported pellet degradation rates in field studies. Thus, dinoflagellates can function as an effective 'protozoan filter' for fecal pellets in the water column.
\end{abstract}

KEY WORDS: Detritivorous feeding $\cdot$ Fecal pellet degradation $\cdot$ Fecal pellet grazing $\cdot$ Detection distance $\cdot$ Microzooplankton $\cdot$ Chemosensory response $\cdot$ Avoidance

\section{INTRODUCTION}

A key role of protozooplankton in the degradation of copepod fecal pellets has been indicated in recent studies. Large protozooplankton (dinoflagellates and ciliates $>20 \mu \mathrm{m}$ ) were key degraders of copepod fecal pellets in a study of fecal pellet degradation by a plankton community collected in Øresund (Denmark) (Poulsen \& Iversen 2008). Microplankton $<200 \mu \mathrm{m}$ were the main degraders of copepod fecal pellets in a field study in the North Sea (Poulsen \& Kiørboe 2006), and Kiørboe (2003) found high pellet clearance rates of the heterotrophic dinoflagellate Noctiluca scintillans in an upwelling plume off the coast of Brazil ( $\left.600 \mathrm{ml} \mathrm{cell}^{-1} \mathrm{~d}^{-1}\right)$. Existing evidence is based on pellet degradation by the size fractions of protozooplankton (dinoflagellates and ciliates) in natural plankton communities and from linear regression linking dinoflagellate concentration and pellet degradation. Also, copepod fecal pellets were observed in food vacuoles of Noctiluca scintillans (Kiørboe 2003). To date no data on pellet grazing rates of heterotrophic dinoflagellates exists from controlled laboratory studies.

Among the protist plankton, most ciliates tend to be filter feeders and feed on very small particles in the plankton (the nano size fraction, 2 to $20 \mu \mathrm{m}$ ). Heterotrophic and mixotrophic dinoflagellates are raptorial feeders and have a much wider range for particle capture and ingestion (3 to $400 \mu \mathrm{m}$ cell length; 
Hansen et al. 1994, Hansen \& Calado 1999, Jeong 1999). This is possible in part because dinoflagellates vary greatly in size and because they have evolved different feeding mechanisms, including direct engulfment, pallium-feeding, and peduncle-feeding (tube-feeding) (Hansen \& Calado 1999, Jeong 1999). The prey-to-dinoflagellate size ratio depends on the feeding mechanism employed by the dinoflagellate. Pallium- and peduncle-feeders are able to feed at higher prey-to-predator size ratios (>10:1) than direct engulfment feeders (5:1) (Jacobson \& Anderson 1986, Hansen et al. 1994, Hansen \& Calado 1999, Berge et al. 2008). Very large fecal pellets $(>400 \mu \mathrm{m})$, likely, pose a problem for most phagotrophic dinoflagellates, either due to the size of the pellet or the number of dinoflagellates needed to remove a significant part of the pellet (pallium- and peduncle-feeders). This fits well with observations from in situ studies showing the lowest degradation rates and highest sedimentation rates for the largest copepod fecal pellets (Turner 2002, Poulsen \& Kiørboe 2006).

Prey detection by dinoflagellates is not well understood. Hydromechanical sensing has not been reported to play a role in prey capture by dinoflagellates. However, chemoattraction has been shown to play a vital role in the particle capture of several different species of dinoflagellates (both heterotrophic and mixotrophic) (Spero 1985, Schnepf \& Drebes 1986, Calado \& Moestrup 1997, Hansen \& Calado 1999, Breckels et al. 2011).

Fecal pellets constitute an important carbon pool in the sea, since copepods occur ubiquitously and in large numbers, constituting up to $80 \%$ of the mesozooplankton biomass in the world's oceans (Humes 1994, Mauchline 1998). Fecal pellets vary in size from small pellets produced by nauplii and copepodites to large pellets produced by calanoid copepods (20 to $600 \mu \mathrm{m}$ in pellet length) (Turner 2002). Correspondingly, sinking rates vary greatly from 2 to $200 \mathrm{~m} \mathrm{~d}^{-1}$ and are determined by pellet size and composition (Komar et al. 1981, Turner 2002). Pellet sinking rates from a field copepod community dominated by small copepods (including Acartia tonsa) were 2 to $25 \mathrm{~m} \mathrm{~d}^{-1}$ (Poulsen \& Kiørboe 2006). Furthermore, sinking rates (mean $\pm \mathrm{SD}$ ) from laboratory studies of pellets similar to the ones used in this study (produced by A. tonsa on Rhodomonas salina) were $35 \pm 29 \mathrm{~m} \mathrm{~d}^{-1}$ (Ploug et al. 2008).

The food quality of a copepod fecal pellet is highly variable depending on the food source, food concentration, pellet production rate, and gut assimilation efficiency of the copepod (Hansen et al. 1996). Pellets, produced under bloom-conditions, are produced with high gut evacuation rates (Hansen et al. 1996), and the content is consequently not digested to the same degree as pellets produced under food-limited conditions. Fecal pellets may even contain intact and viable phytoplankton cells (Wotton 1994, Dubischar \& Bathmann 2002), thus representing high quality food particles for phagotrophic dinoflagellates.

Field evidence of detritivorous feeding by dinoflagellates alters our conventional view of energy flow and carbon cycling in marine planktonic food webs. Recycling of fecal pellet material directly through protozooplankton reduces total respiration losses compared to the microbial loop, as fewer trophic levels are passed in the recycling process (Azam et al. 1983). However, direct proof of pellet feeding by dinoflagellates has to our knowledge not been published prior to this study.

The aim of this study was therefore to obtain evidence of pellet feeding by dinoflagellates through visual observation and grazing experiments, and to study governing factors for this behavior.

\section{MATERIALS AND METHODS}

\section{Cultures}

Cultures were kept in a walk-in temperature regulated room at $18 \pm 1^{\circ} \mathrm{C}$ following a light:dark cycle of 16:8 h (Table 1). Mixotrophic dinoflagellates and food alga were kept in seawater based f/20 medium (Guillard 1975) of a salinity of $28 \%$ on a light table (cool white, $80 \mu \mathrm{mol}$ photons $\mathrm{m}^{-2} \mathrm{~s}^{-1}$ ). Heterotrophic dinoflagellates were kept on a plankton wheel $(1 \mathrm{rpm})$, in sterilized $0.2 \mu \mathrm{m}$ filtered seawater (FSW, $\sim 30 \%$ ), and in dim light $\left(0.2 \mu \mathrm{mol} \mathrm{E} \mathrm{m}^{-2} \mathrm{~s}^{-1}\right)$ to control prey growth. Heterotrophic dinoflagellates were isolated from Helsingør harbour, Denmark by L. K. Poulsen (except Diplopsalis lenticula, Table 1). For salinity and temperature conditions for each dinoflagellate species in the stock culture see Table 3.

\section{Visual observation of pellet feeding}

Observation of pellet feeding was conducted by offering 7 dinoflagellate species (Table 1) fresh ( $<30$ min old) fecal pellets produced as described for pellet grazing and growth experiments (see below). Photographs were frame grabbed with VirtualDub 1.8.5 and represent live dinoflagellate cells feeding on copepod fecal pellets or fragments of pellets (see Figs. $1 \& 3$ ). 
Table 1. Algae species and culture conditions. SCCAP = Scandinavian Culture Collection of Algae \& Protozoa (www. sccap.dk). Hel lab = The Marine Biological Laboratory, Helsingør, Denmark. Helsingør = the culture was isolated from Helsingør harbour by L. K. Poulsen and kept at the Marina Biological Laboratory in Helsingør. Germany = the culture was obtained from Urban Tillmann, Biosciences/Ecological chemistry, Alfred Wegener Institute, Germany. UA = the culture is currently unavailable and unidentified but the gene sequence will be deposited in GenBank during 2011

\begin{tabular}{|c|c|c|c|c|c|c|}
\hline Species & $\begin{array}{l}\text { Strain } \\
\text { number }\end{array}$ & $\begin{array}{l}\text { Culture } \\
\text { origin }\end{array}$ & $\begin{array}{l}\text { Food } \\
\text { alga }\end{array}$ & $\begin{array}{c}\text { Feeding } \\
\text { mechanism }\end{array}$ & Medium & 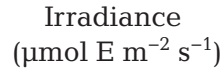 \\
\hline \multicolumn{7}{|l|}{ Food algae (algal prey) } \\
\hline Ditylum brightwellii $(D b)$ & K-1041 & SCCAP & & & $\mathrm{f} / 20+\mathrm{Si}$ & 80 \\
\hline Heterocapsa triquetra $(H t)$ & NC-98 & SCCAP & & & $\mathrm{f} / 20$ & 80 \\
\hline Lingulodinium polyedrum $(L p)$ & K-0982 & SCCAP & & & $\mathrm{f} / 20$ & 80 \\
\hline Teleaulax amphioxeia (Ta) & K-0434 & Hel lab & & & $f / 20$ & \\
\hline Rhodomonas salina $(R s)$ & K-0294 & SCCAP & & & $\mathrm{f} / 20$ & 80 \\
\hline Mesodinium rubrum $(\mathrm{Mr})$ & & Helsingør & $T a$ & & $\mathrm{f} / 20$ & 80 \\
\hline \multicolumn{7}{|l|}{ Mixotrophic dinoflagellates } \\
\hline Dinophysis acuminata & & Helsingør & $M r$ & Peduncle & $\mathrm{f} / 20$ & 80 \\
\hline Karlodinium armiger & K-0668 & SCCAP & $R s$ & Peduncle & $\mathrm{f} / 20$ & 80 \\
\hline Gymnodinoid dinofl. (UA) & Gy1 & SCCAP & - & Peduncle & $\mathrm{f} / 20$ & 80 \\
\hline \multicolumn{7}{|l|}{ Heterotrophic dinoflagellates } \\
\hline Diplopsalis lenticula & & Germany & $D b$ & Pallium & FSW & 0.2 \\
\hline Gyrodinium dominans & & Helsingør & $H t$ & Direct engulfment & FSW & 0.2 \\
\hline Gyrodinium spirale & & Helsingør & $H t / L p$ & Direct engulfment & FSW & 0.2 \\
\hline Protoperidinium depressum & & Helsingør & $D b$ & Pallium & FSW & 0.2 \\
\hline
\end{tabular}

\section{Behavioral experiments}

The feeding behavior of 2 mixotrophic (Karlodinium armiger, a gymnodinoid dinoflagellate, Gy1) and 1 heterotrophic species (Gyrodinium dominans) towards freshly produced copepod fecal pellets was investigated ( 1 replicate). These species were chosen since pilot studies had shown that they represented 3 different responses to pellets and pellet age. Heterotrophic dinoflagellates were used for experimentation when the food organisms were depleted to exclude other food organisms from pellet grazing experiments (starvation $<1 \mathrm{~d}$ ). Karlodinium armiger was kept without food for $1 \mathrm{wk}$ prior to experimentation. Gy1 was grown in light without food (Table 1). Pellets used in this experiment came from 2 to 5 Acartia tonsa females placed in a $17 \mathrm{ml}$ multi-dish well ( 6 wells) filled with $0.2 \mu \mathrm{m}$ filtered f/20 medium and fed saturating concentrations of Rhodomonas salina. The females were allowed to feed for $>1 \mathrm{~h}$ before pellet production to ensure acclimation to high food concentrations and production of uniform pellets. A pellet was collected immediately after egestion and washed by transferring the pellet into a new well filled with $0.2 \mu \mathrm{m}$ filtered $\mathrm{f} / 20$ medium, the same medium used for culturing of the dinoflagellates. Recording was commenced within 5 to $15 \mathrm{~min}$ of pellet egestion. Pellet age at recording start was therefore between 5 and $15 \mathrm{~min}$. Behavior experi- ments were performed at $15 \pm 1^{\circ} \mathrm{C}$ and the dinoflagellates were acclimated to this temperature $>24 \mathrm{~h}$ prior to experimentation. Dinoflagellate behavior was filmed in a $17 \mathrm{ml}$ multi-dish well placed under an inverted microscope (Olympus CK2) at $4 \times$ magnification (front lens). Start and end concentrations (after $48 \mathrm{~h}$ of incubation) are presented in Table 2. Recording was conducted with an infrared (IR) digital video camera (uEye 1540-C, IDS Imaging). The feeding behavior of the 3 dinoflagellate species towards a copepod fecal pellet was recorded in low light (cool

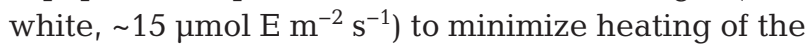
water. The fecal pellet was kept in focus during recording, and care was taken not to disturb the multi-dish and the water mass around the pellet.

Dinoflagellate feeding behaviors were quantified and analyzed in time intervals of 2 min during the

Table 2. Start $(t=0 \mathrm{~h})$ and end $(t=48 \mathrm{~h})$ dinoflagellate cell concentrations (cells $\mathrm{ml}^{-1}$ ) in the behavior experiments. The dinoflagellates were allowed to feed on 1 fecal pellet for $48 \mathrm{~h}$. The fecal pellet was produced on Rhodomonas salina by female Acartia tonsa copepods. na: not available

\begin{tabular}{|lrr|}
\hline Species & Start & End \\
\hline Gyrodinium dominans & 143 & 20 \\
Karlodinium armiger & 3490 & 4670 \\
Gymnodinoid dinofl. (Gy1) & 1320 & na \\
\hline
\end{tabular}


first 142 min and then for 30 min after 24 and after $48 \mathrm{~h}$ of incubation (total time analyzed was $112 \mathrm{~min}$ ). Three types of dinoflagellate behavior were defined, analyzed and quantified: physical encounters, avoidance, and feeding attempts. A physical encounter was observed when a dinoflagellate cell came in direct physical contact with the surface of the pellet. The avoidance response for all 3 dinoflagellate species was observed as an immediate decrease in swimming speed or cessation of swimming upon detection of the signal from the pellet, followed by a change in swimming direction (tumble) away from the pellet at an angle of $>90^{\circ}$ to $<270^{\circ}$, succeeded by normal swimming (Jennings 1906, Tamar 1965, Jakobsen et al. 2006). Turns of $<90^{\circ}$ could be random and not a direct avoidance reaction to the pellet signal. Observation of feeding was called a feeding attempt since we could not distinguish between an attempt and actual feeding at the low magnification needed to observe detection distance and behavior towards the pellet. A feeding attempt for Karlodinium armiger and Gy1 was observed when a cell remained in physical contact with the pellet in the same position for at least $6 \mathrm{~s}$, often accompanied by a rocking back and forth by the cell. Physical encounters lasted $<4$ s. A feeding attempt for Gyrodinium dominans was observed when a G. dominans cell attached itself to the pellet surface by a filament. Direct engulfment was not observed by $G$. dominans in this experiment.

All 3 species were able to detect the cue from the pellet at some distance, defined in this study as detection distance; the distance (in $\mu \mathrm{m}$ ) from the fecal pellet where a recognizable change in the swimming behavior of a dinoflagellate swimming towards the pellet was observed. Dinoflagellates swimming in normal cruise mode and entering from the periphery of the field of view were followed towards the pellet. Detection resulted in an abrupt decrease in swimming speed or a short pause in swimming, after which the dinoflagellate would begin circling to locate the cue (attraction) or reverse its swimming direction (avoidance).

Swimming tracks were made by analysing video recordings frame by frame (1 frame $=0.07 \mathrm{~s}), 1 \mathrm{dot}$ representing a time interval of $0.2 \mathrm{~s}$ (see Fig. 4). The tracks were made from the recordings in the time interval of 6 to $8 \mathrm{~min}$ for the 3 species (see Fig. 2, 7 minute time interval). Only cells moving from the periphery of the view field and in the plane of the bottom of the well were used in the analysis, which therefore limited the number of tracks.

\section{Pellet grazing and growth experiments}

Grazing experiments on copepod fecal pellets were carried out on 2 mixotrophic (Karlodinium armiger, a gymnodinoid dinoflagellate, Gy1) and 3 heterotrophic species (Gyrodinium dominans, $G$. spirale, Protoperidinium depressum) with constant pellet concentration and varying dinoflagellate concentration (4 species with 5 densities each in triplicate; and 1 species ( $P$. depressum) with 1 density in triplicate). These species were chosen to represent both heterotrophic and mixotrophic dinoflagellates and small $(<20 \mu \mathrm{m})$ and large $(>20 \mu \mathrm{m})$ dinoflagellates. Furthermore, field experiments had indicated that $G$. spirale and $P$. depressum were important grazers of copepod fecal pellets (Poulsen \& Iversen 2008). All fecal pellets were based on Rhodomonas salina as prey for the copepods. Experimental conditions are listed in Table 3 and were similar to stock culture conditions with the exception of irradiance for the 2 mixotrophic species. Irradiance was kept lower in the stock culture of $K$. armiger to control the food organism ( $R$. salina). All dinoflagellates were acclimated to experimental light, temperature and salinity conditions for $>1 \mathrm{wk}$ prior to experimentation. Exponentially growing cultures of the 3 heterotrophic dinoflagellate species were used for experimentation when the food organisms were depleted to exclude other food organisms from pellet grazing experiments (starvation $<1 \mathrm{~d}$ ). $K$. armiger was kept without food for 1 wk prior to experimentation. Gy1 was grown in light without food. Experimental concentrations of dinoflagellates and fecal pellets were chosen based on reported data on natural abundances in coastal waters (Hansen 1992, Poulsen \& Kiørboe 2006, Gribble et al. 2007).

A grazing experiment with 2 food treatments was conducted with the heterotrophic dinoflagellate Protoperidinium depressum specifically to investigate the importance of the fecal pellet food source for dinoflagellate grazing and growth. The 2 food treatments were pellets produced on Rhodomonas salina (a cryptophyte) or Ditylum brightwellii (a diatom). The treatments were incubated in parallel under the same conditions with $P$. depressum from the same stock culture. The 2 pellet types were produced as described below. Each treatment was conducted with only $1 P$. depressum concentration and 1 pellet concentration (triplicate, $\mathrm{n}=3$ ) (Table 3).

Copepod fecal pellets were produced by adult Acartia tonsa feeding on Rhodomas salina at saturating food concentrations (>713 $\mu \mathrm{g} \mathrm{C}^{-1}$; Kiørboe et al. 
Table 3. Experimental conditions for grazing and growth experiments. Five dinoflagellate species were offered fecal pellets produced on Rhodomonas salina (Rs) by adult Acartia tonsa. Classic grazing experiments with varying dinoflagellate concentration (5 concentrations, triplicate) and constant pellet concentration were conducted. A food source grazing experiment with 2 pellet treatments ( $R s$ and Ditylum brightwellii, $D b$ ) was conducted with Protoperidinium depressum, with only 1 grazer concentration and pellet concentration used (triplicate). All experiments were incubated for $24 \mathrm{~h}$. rpm $=$ rounds per minute of the plankton wheel

\begin{tabular}{|c|c|c|c|c|c|c|c|c|c|}
\hline $\begin{array}{l}\text { Experimental } \\
\text { dinoflagellate } \\
\text { species (grazer) }\end{array}$ & $\begin{array}{c}\text { Grazer } \\
\left(\text { cells ml }{ }^{-1}\right)\end{array}$ & $\begin{array}{c}\text { Food } \\
\text { source }\end{array}$ & $\begin{array}{c}\text { Pel } \\
\begin{array}{c}\text { Conc. } \\
\left(\text { no. } \mathrm{ml}^{-1}\right)\end{array}\end{array}$ & $\begin{array}{l}\text { Length } \\
(\mu \mathrm{m})\end{array}$ & $\begin{array}{c}\text { Vol. }\left(\times 10^{4}\right. \\
\left.\mu \mathrm{m}^{3}\right)\end{array}$ & rpm & $\begin{array}{l}\text { Temp } \\
\left({ }^{\circ} \mathrm{C}\right)\end{array}$ & $\begin{array}{l}\text { Salinity } \\
\qquad \% \text { o })\end{array}$ & $\begin{array}{c}\text { Irradiance } \\
(\mu \mathrm{mol} E \\
\left.\mathrm{m}^{-2} \mathrm{~s}^{-1}\right)\end{array}$ \\
\hline Gyrodinium dominans & 2.3 & $R s$ & 0.6 & $46-79$ & $3.2-7.7$ & 0.9 & $18 \pm 1$ & 30 & Dark \\
\hline Gyrodinium spirale & $0.5-2.5$ & Rs & 1.5 & $48-159$ & $14.5-4.7$ & 0.9 & $18 \pm 1$ & 30 & 0.2 \\
\hline Karlodinium armiger & $100-400$ & $R s$ & 1.5 & $48-159$ & $14.5-4.2$ & 0.9 & $18 \pm 1$ & 28 & 130 \\
\hline Gymnodinoid dinofl. (Gy1) & $100-1000$ & $R s$ & 1.5 & $48-159$ & $14.5-4.2$ & 0.9 & $18 \pm 1$ & 28 & 130 \\
\hline Protoperidinium depressum & 0.8 & $R s$ & 0.4 & $165-184$ & $9-28.4$ & 2 & $10 \pm 1$ & 15 & Dark \\
\hline Protoperidinium depressum & 0.8 & $D b$ & 0.4 & $165-184$ & $9-28.4$ & 2 & $10 \pm 1$ & 15 & Dark \\
\hline
\end{tabular}

1985) for 18 to $20 \mathrm{~h}$, except for the Gyrodinium spirale grazing experiment where the pellets were $<5 \mathrm{~h}$ old when used for experimentation. Adult A. tonsa were acclimated to high food concentrations of $R$. salina for $>18 \mathrm{~h}$ before pellet production. After production the pellets were separated from the copepods by double filtration through a $180 \mu \mathrm{m}$ mesh (upper mesh) and a $30 \mu \mathrm{m}$ mesh (lower mesh). The pellet sample concentrated in the $30 \mu \mathrm{m}$ mesh was kept water covered (to minimize disruption) and gently washed in FSW to remove phytoplankton. The pellets were diluted in the growth medium of the experimental dinoflagellate, to ensure that the dinoflagellate was acclimated to the medium, and then offered immediately to the dinoflagellates. Pellet production time, separation and dilution resulted in pellet ages at the start of incubation of between $20 \mathrm{~min}$ and $20 \mathrm{~h}$. Different size ranges of pellets for experimentation were obtained by double filtration using different mesh sizes (50 and $15 \mu \mathrm{m}$ double mesh for G. dominans and 200 and $30 \mu \mathrm{m}$ for the Protoperidinium depressum grazing experiment).

After incubation, grazing experiments were fixed with acidic Lugol's solution (final concentration $2 \%$ ) added directly into the experimental scintillation vials $(25 \mathrm{ml})$ or tissue culture bottles $(60 \mathrm{ml})$. Pellet fragments were counted as half a pellet and average volume was calculated from measurements of length and width of at least 30 pellets per bottle, when possible. Ingestion and clearance rates were calculated as described in Jakobsen \& Hansen (1997). Only incubations with a pellet loss of between 10 and $50 \%$ (after subtraction of the bacterial degradation in control bottles) were used to calculate the average clearance, ingestion and growth rates.

\section{Statistical analysis}

The differences in clearance and ingestion of Protoperidinium depressum on copepod fecal pellets produced on either a diatom Ditylum brightwellii or a cryptophyte Rhodomonas salina were compared using a Student $\mathrm{s} t$-test. The grazing rates obtained in grazing experiments with Gyrodinium dominans, G. spirale, Gy1, Karlodinium armiger and Protoperidinium depressum were tested by comparing pellet concentration in the controls and incubations, using a Student $\mathrm{s} t$-test. Whether the growth rates obtained in the grazing experiments for $P$. depressum $(R$. salina, $\mathrm{n}=3$; and $D$. brightwellii-based pellets, $\mathrm{n}=3$ ) and $G$. spirale $(R$. salina pellets, $\mathrm{n}=5)$ were statistically significantly different from 0 was tested by calculating the $t$-value and df for each experiment and comparing this with a $t$-distribution table at the significance level of $\alpha=0.05$. The responses of attraction (= physical encounters + feeding attempts) and avoidance were tested for departure from random behavior (= 1:1 ratio) using a $\chi^{2}$ test with Yates correction for continuity.

\section{RESULTS}

\section{Visual observation of pellet feeding by dinoflagellates}

The 2 mixotrophic dinoflagellates (Karlodinium armiger and a gymnodinoid dinoflagellate, Gy1) and all 4 heterotrophic dinoflagellates (Diplopsalis lenticula, Gyrodinium dominans, G. spirale and Protoperidinium depressum) were observed to feed on Rhodomonas salina-based fecal pellets produced by 
the copepod Acartia tonsa (Figs. 1, 2 \& 3, Tables 4 \& 5). K. armiger and Gy1 fed on fecal pellets by use of a peduncle. Gy1 mainly avoided fecal pellets and pellet feeding was very rare (Fig. 2, Table 5). The small size of $K$. armiger and Gy1 (average length 14 to $18 \mu \mathrm{m}$ ) compared to an $A$. tonsa pellet (length 50 to $190 \mu \mathrm{m})$ allowed them to remove only small pieces at a time ( 5 to $15 \mu \mathrm{m}_{i}$ Berge et al. 2008). G. dominans (length 18 to $43 \mu \mathrm{m}$ ) and G. spirale (length 60 to $160 \mu \mathrm{m})$ both ingested fecal pellets by direct engulfment. G. spirale was observed to ingest intact fecal pellets sized up to 6 times its own length. G. spirale is able to stretch its cell membrane and is, furthermore, able to bend pellets during engulfment, folding the pellet into a food vacuole. The smaller $G$. dominans ingested fragments of pellets (maximum size $<1 / 2$ pellet; $\sim 40 \mu \mathrm{m}$, Fig. 1). D. lenticula and P. depressum are pallium feeders, and enveloped intact fecal pellets with a pallium outside the dinoflagellate theca. The 4 heterotrophic dinoflagellates attached to the fecal pellet by an attachment filament (also called a tow filament), and were observed to swim with the fecal pellet attached to them or in a food vacuole. $K$. armiger and Gy1 also used an attachment filament, but were unable to swim with the pellet due to their small size. Thus, dinoflagellate size and feeding mechanism appear to be important factors for their

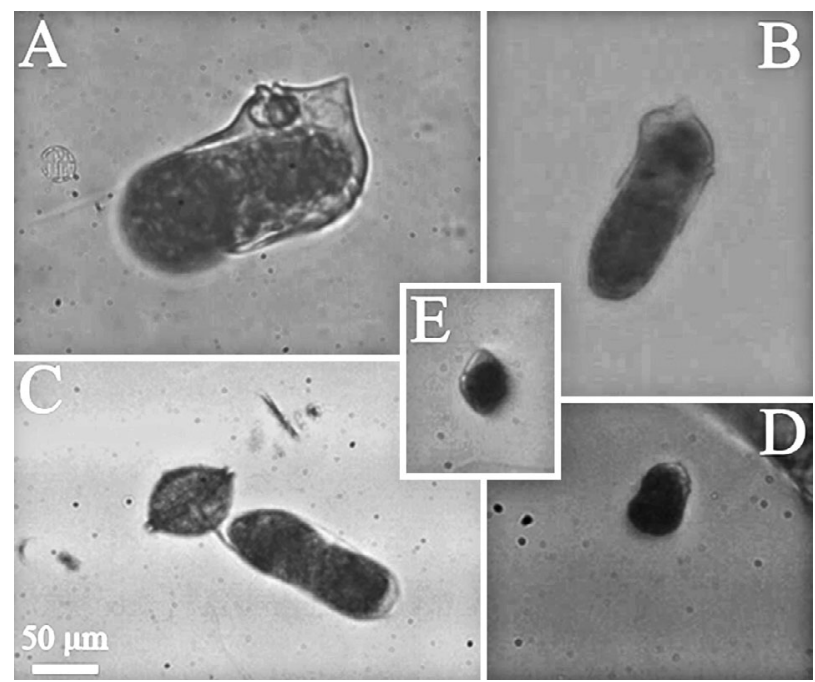

Fig. 1. Copepod fecal pellet feeding by heterotrophic dinoflagellates. (A,B) Gyrodinium spirale directly engulfing a copepod fecal pellet while swimming. (C) Diplopsalis lenticula towing a pellet in a pallium. (D,E) Gyrodinium dominans with a pellet fragment in a large food vacuole. Fecal pellets were produced by adult Acartia tonsa on Rhodomonas salina. Pictures were frame grabbed from video recordings of live, swimming, dinoflagellate cells. The scale bar applies to all micrographs

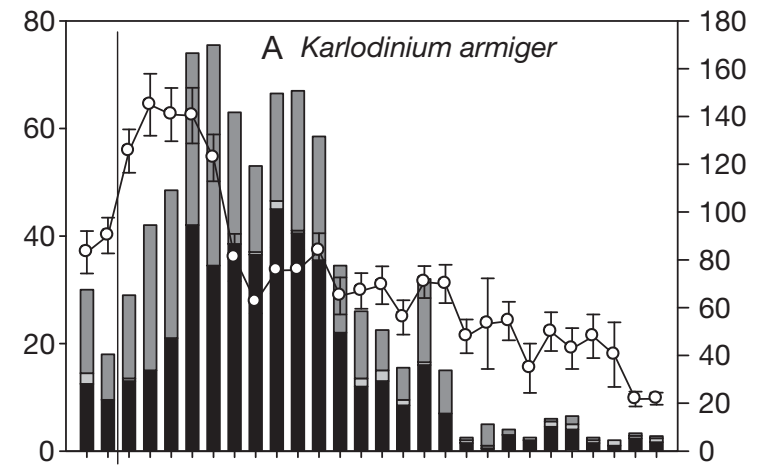

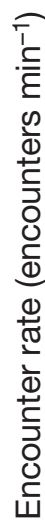
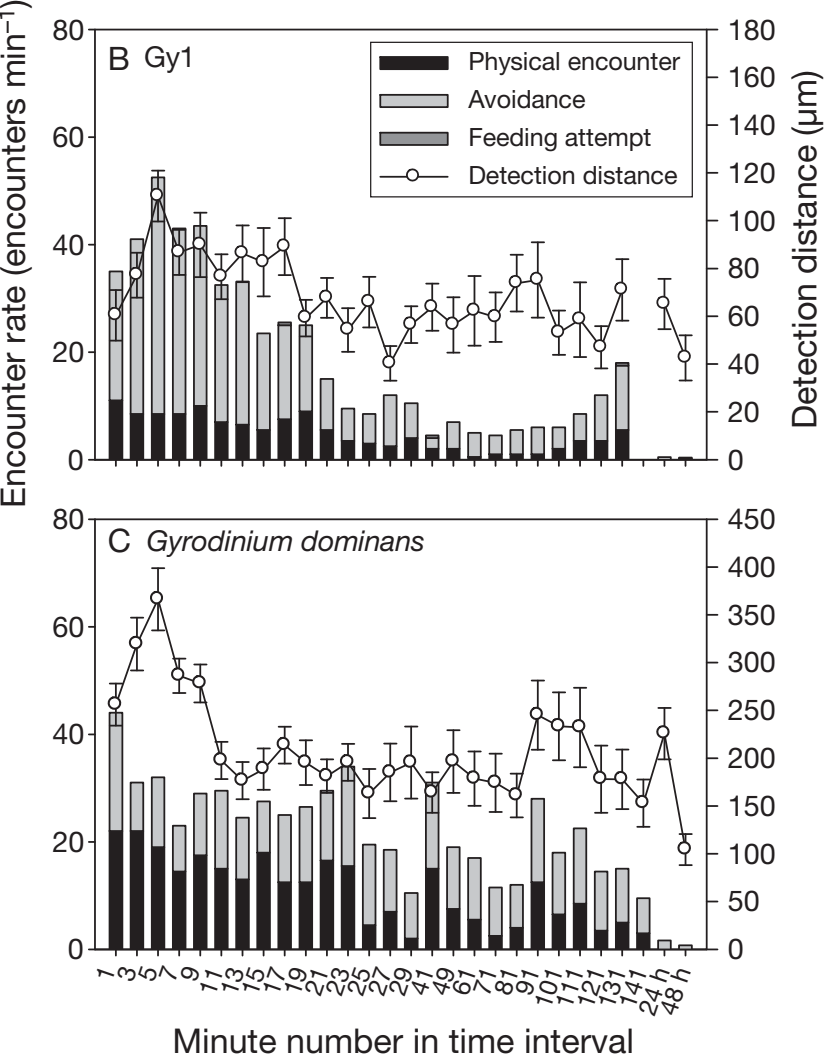

Fig. 2. Behavior of (A) Karlodinium armiger, (B) an unidentified gymnodinoid dinoflagellate (Gy1), and (C) Gyrodinium dominans towards copepod fecal pellets. Three types of dinoflagellate behavior were defined, analyzed and quantified in time intervals of 2 min: physical encounters, avoidance, feeding attempts. Detection distance (note different scaling) was the distance from the pellet surface from which the dinoflagellate visibly detected the chemical cue from the pellet. The $x$-axis is the average minute number in the time interval. Total analyzed time was $112 \mathrm{~min}$. The number of observations is represented as the average observations per minute to obtain encounter rate

ability to ingest intact pellets. Furthermore, large dinoflagellates are able to swim with the attached fecal pellets during feeding, thus counter-acting the high sinking rates of copepod fecal pellets. 


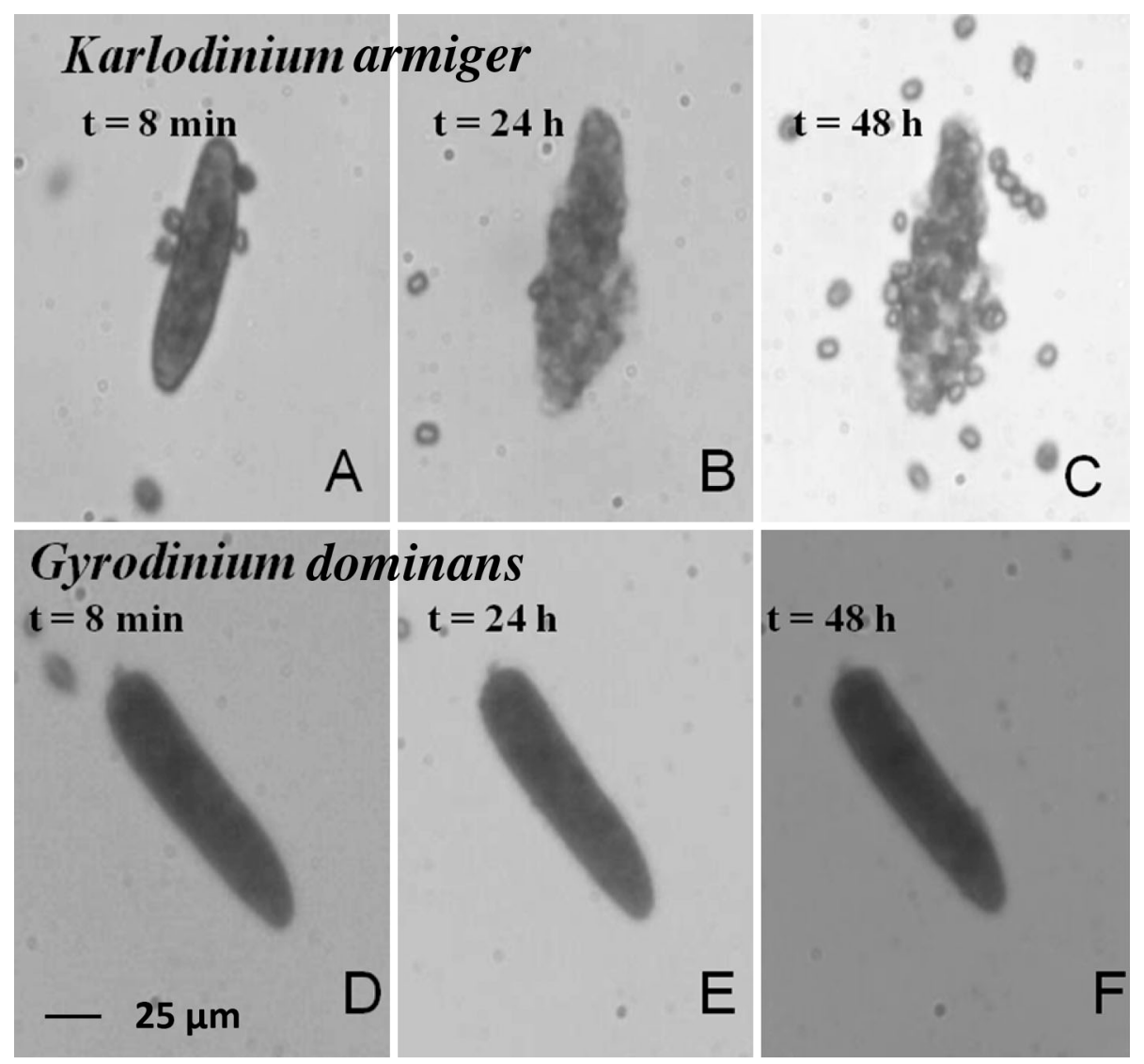

Fig. 3. Ingestion of copepod pellet material by (A-C) Karlodinium armiger and (D-F) Gyrodinium spirale during the behavior experiment. The condition of the pellets is shown after $8 \mathrm{~min}, 24 \mathrm{~h}$ and $48 \mathrm{~h}$. The scale bar applies to all micrographs

Table 4. Copepod fecal pellet feeding (direct engulfment, pallium- or peduncle-feeding) by dinoflagellates

\begin{tabular}{|c|c|c|c|}
\hline Species & etection & $\begin{array}{l}\text { Pellet } \\
\text { grazing }\end{array}$ & $\begin{array}{l}\text { Pellet sizes } \\
\text { grazed }(\mu \mathrm{m})\end{array}$ \\
\hline \multicolumn{4}{|l|}{ Mixotrophic } \\
\hline Dinophysis acuminata & Yes & No & - \\
\hline Karlodinium armiger & Yes & Yes & $40-190$ \\
\hline Gymnodinoid dinofl. (Gy1) & Yes & Yes $^{\mathrm{a}}$ & $40-190$ \\
\hline \multicolumn{4}{|l|}{ Heterotrophic } \\
\hline Diplopsalis lenticula & Yes & Yes & $40-190$ \\
\hline Gyrodinium dominans & Yes & Yes & $40-90$ \\
\hline Gyrodinium spirale & Yes & Yes & $40-190$ \\
\hline Protoperidinium depressum & Yes & Yes & $40-190$ \\
\hline
\end{tabular}

\section{Chemical sensing of pellets by dinoflagellates}

Three types of dinoflagellate behavior were defined, analyzed and quantified: physical encounters, avoidance, and feeding attempts. The selected dinoflagellates for this detailed study of feeding
Table 5. Behavior experiment. The total number of pellet encounters, encounter rate (total encounters/average cell concentration), and \% of total encounters that led to feeding attempts or avoidances, during the total 112 min analyzed. The number of encounters cell ${ }^{-1}$ of the unidentified gymnodinoid dinoflagellate (Gy1) could not be estimated due to lack of data (Table 2)

\begin{tabular}{|c|c|c|c|c|}
\hline \multirow[t]{2}{*}{ Species } & \multicolumn{2}{|c|}{ No. of encounters } & \multirow{2}{*}{$\begin{array}{c}\text { Feeding } \\
\text { attempt }(\%)\end{array}$} & \multirow{2}{*}{$\begin{array}{c}\text { Avoidance } \\
(\%)\end{array}$} \\
\hline & Total & Per cell & & \\
\hline $\begin{array}{c}\text { Gyrodinium } \\
\text { dominans }\end{array}$ & 1209 & 15 & 0 & 53 \\
\hline $\begin{array}{l}\text { Karlodinium } \\
\text { armiger }\end{array}$ & 951 & 0.2 & 73 & 3 \\
\hline Gy1 & 976 & - & 0.3 & 75 \\
\hline
\end{tabular}

behavior, Gyrodinium dominans, Karlodinium armiger, and Gy1 all showed a significant response of either attraction or avoidance to the chemical cue leaking from the copepod fecal pellets (Figs. $2 \& 4$ ). $K$. armiger showed significant attraction (physical encounters + feeding attempts) towards the chemical 


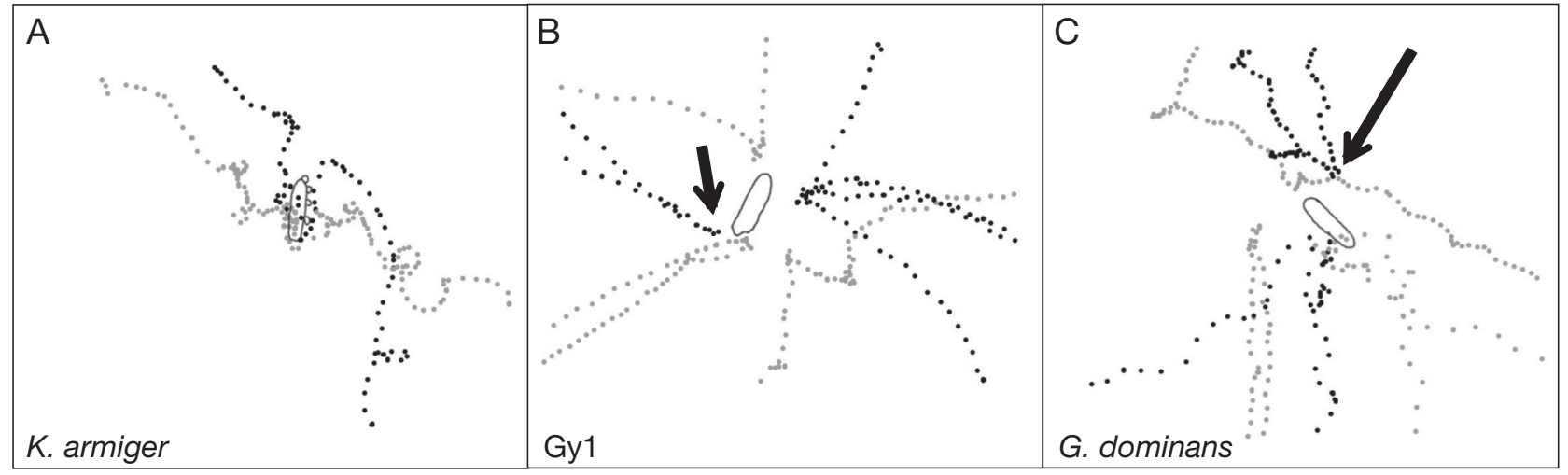

Fig. 4. Swimming tracks of (A) Karlodinium armiger, (B) an unidentified gymnodinoid dinoflagellate (Gy1), and (C) Gyrodinium dominans around the copepod fecal pellet in the behavior experiment. Tracks were made by analysing video recordings frame by frame $(1$ frame $=0.07 \mathrm{~s}), 1$ dot $=$ time interval of $0.2 \mathrm{~s}$. Arrow: avoidance response. Fecal pellet length: (A) $158 \mu \mathrm{m}$, (B) $184 \mu \mathrm{m}$, and (C) $171 \mu \mathrm{m}$

cue of the pellet $\left(\mathrm{c}^{2}\right.$ Yates correction $\left.=838, \mathrm{df}=1, \mathrm{p}<0.01\right)$, whereas G. dominans ( $\mathrm{c}^{2}$ Yates correction $=4.3, \mathrm{df}=1, \mathrm{p}<$ $0.05)$ and Gy1 $\left(\mathrm{c}^{2}\right.$ Yates correction $\left.=243, \mathrm{df}=1, \mathrm{p}<0.01\right)$ showed significant avoidance.

Most encounters were observed within the first hour of recording (Fig. 2). Feeding attempts were observed for all 3 species, but were rare for $G$. dominans and Gy1 (0 and 0.3\%). Both species and particularly Gy1 had a significant avoidance response towards the pellet (53 and 75\%) (Fig. 2, Table 5). However, a feeding response of G. dominans was observed while the freshly added pellet was sinking towards the bottom. More than $6 \mathrm{G}$. dominans cells attached themselves to the intact pellet, dragging it around in the multi dish delaying recording start. After 3 to $5 \mathrm{~min}$ the feeding response ceased, the filaments towing the pellet were retracted, and the pellet was allowed to settle on the bottom. Analysis during the next $48 \mathrm{~h}$ of incubation showed that no feeding attempts were made despite the high pellet encounters per $G$. dominans cell (Table 5). Thus, G. dominans has a feeding response only towards freshly egested pellet $(<20 \mathrm{~min}$ old). Contrasting this, $73 \%$ of the total encounters resulted in feeding attempts for $K$. armiger. Most feeding attempts were observed within the first hour of recording and decreased over time. This demonstrated that the age or rather the quality of the chemical cue from the pellet is very important for the feeding response of dinoflagellates such as G. dominans, whereas $K$. armiger fed throughout the experiment.

The propagation of the chemical cue was determined indirectly by the detection distance of the dinoflagellates. The detection distance increased after incubation start and reached a maximum after 4 to $8 \mathrm{~min}$. Thereafter, detection distance decreased slowly or stayed constant during the following $48 \mathrm{~h}$ of incubation (Fig. 2). The maximum average detection distance of the dinoflagellates was $145 \pm 13 \mu \mathrm{m}$ for Karlodinium armiger, $110 \pm 11 \mu \mathrm{m}$ for Gy1, and $366 \pm$ $33 \mu \mathrm{m}$ for Gyrodinium dominans (average for $2 \mathrm{~min}$ time intervals \pm SE, Fig. 2).

Growth was observed for Karlodinium armiger after the $48 \mathrm{~h}$ of incubation, and only in the behavior experiment with $K$. armiger was a significant removal of pellet material observed (Fig. 3A-C). Removal of pellet material was not observed for Gy1 since the pellet was still basically intact and would be counted as 1 pellet. The pellet in the experiment with Gyrodinium dominans remained intact and with an intact peritrophic membrane during the $48 \mathrm{~h}$ of filming. This indicates insignificant degradation by bacteria in the behavior experiments (Fig. 3D-F).

\section{Importance of dinoflagellate grazing on copepod fecal pellets}

Using natural concentrations of dinoflagellates and copepod fecal pellets, average ingestion rates of 0.21 and 0.11 pellets cell ${ }^{-1} \mathrm{~d}^{-1}$ and clearance rates of 0.21 and $0.32 \mathrm{ml} \mathrm{cell}^{-1} \mathrm{~d}^{-1}$ were obtained for Gyrodinium spirale and Protoperidinium depressum, respectively, when fed with Rhodomonas salinabased fecal pellets produced by adult Acartia tonsa (Table 6). Feeding on the pellets led to average growth rates of 0.69 and $0.08 \mathrm{~d}^{-1}$, for G. spirale and $P$. depressum, respectively (Table 6). However, only the growth rate obtained for $G$. spirale was signifi- 
Table 6. Gyrodinium spirale and Protoperidinium depressum grazing experiments. Rates of clearance, ingestion and growth (average $\pm \mathrm{SE}$ ) from 3 grazing experiments offering $G$. spirale pellets produced on Rhodomonas salina, and $P$. depressum pellets produced on $R$. salina or Ditylum brightwelli. Only incubations with a pellet loss of 10 to $50 \%$ were used to calculate the average rates. No. replicates $=$ number of incubations meeting this condition. Two $P$. depressum experiments were conducted in parallel with 1 concentration of $P$. depressum and pellets (triplicate). The G. spirale experiment was conducted with constant pellet concentration and 5 different G. spirale concentrations (triplicate). Clearance and ingestion rates were calculated from average pellet concentration according to Jakobsen \& Hansen (1997). Average pellet volumes were $14.7 \pm 8.3 \times 10^{4} \mu \mathrm{m}^{3}$ pellet $^{-1}$ in the $P$. depressum experiments and $5.8 \pm 1.3 \times 10^{4} \mathrm{~mm}^{3}$ pellet $^{-1}$ in the $G$. spirale experiment

\begin{tabular}{|c|c|c|c|c|c|}
\hline Grazing experiments & No. replicates & $\begin{array}{c}\text { Clearance } \\
\left(\mathrm{ml}^{-1} \mathrm{cell}^{-1} \mathrm{~d}^{-1}\right)\end{array}$ & $\begin{array}{c}\text { Ingestion } \\
\left(\text { pellets cell }{ }^{-1} \mathrm{~d}^{-1}\right)\end{array}$ & $\begin{array}{c}\text { Ingestion vol. } \\
\left(\times 10^{4} \mathrm{\mu m}^{3} \text { cell }^{-1} \mathrm{~d}^{-1}\right)\end{array}$ & $\begin{array}{c}\text { Growth } \\
\left(\mathrm{d}^{-1}\right)\end{array}$ \\
\hline \multicolumn{6}{|l|}{ Gyrodinium spirale } \\
\hline Rhodomonas salina pellets & 5 & $0.21 \pm 0.04$ & $0.21 \pm 0.04$ & $1.23 \pm 0.25$ & $0.69 \pm 0.13$ \\
\hline \multicolumn{6}{|l|}{ Protoperidinium depressum } \\
\hline Ditylum brightwellii pellets & 3 & $0.42 \pm 0.29$ & $0.13 \pm 0.08$ & $1.99 \pm 1.23$ & $-0.07 \pm 0.02$ \\
\hline Rhodomonas salina pellets & 3 & $0.32 \pm 0.12$ & $0.11 \pm 0.04$ & $1.59 \pm 0.53$ & $0.08 \pm 0.06$ \\
\hline
\end{tabular}

cantly different from 0 ( $t$ - distribution, $\mathrm{p}<0.001)$. In the experiment where $P$. depressum was offered both $R$. salina and Ditylum brightwellii-based pellets, there was no significant difference between the clearance and ingestion rates obtained on the 2 types of pellets ( $t$-test, $p>0.05$ ), and the growth rates were not significantly different from 0 ( $t$-distribution, $\mathrm{p}>0.05)$. Thus, fecal pellets do provide $G$. spirale and $P$. depressum with an alternative food source, which can support growth for G. spirale and maintain the metabolism for $P$. depressum. There was no indication of selectivity between the 2 fecal pellet types offered to $P$. depressum.

Significant grazing rates were not obtained for the smaller dinoflagellates Gyrodinium dominans, Karlodinium armiger and Gy1 ( $t$-test, $\mathrm{p}>0.05$ ) when offered adult Acartia tonsa fecal pellets at low natural cell concentrations of these dinoflagellates ( 2 to 1000 cells ml ${ }^{-1}$ ). K. armiger, nevertheless, grazed significantly on a $R$. salina pellet in the behavior experiment when present in higher cell concentrations (3400 to 4700 cells ml ${ }^{-1}$, Fig. 3A-C), illustrating that the impact of pellet degradation by dinoflagellates is dependent on the concentration of the dinoflagellates.

\section{DISCUSSION}

\section{Dinoflagellate feeding on copepod fecal pellets}

The food sources of mixotrophic and heterotrophic dinoflagellates are generally believed to be other protists (e.g. Jeong 1999, Hansen \& Calado 1999), although a couple of studies have shown that some species are able to feed on copepod eggs, nauplii (Kimor 1979, Jeong 1994), and even on live fish
(Vogelbein et al. 2002). Here, we document for the first time in the laboratory that a number of phagotrophic dinoflagellates, which are common in the marine plankton, exploit copepod fecal pellets as a source of food. Their 3 main food-uptake mechanisms allow ingestion of fecal pellets: pallium-feeding, peduncle (tube)-feeding and direct engulfment. While we found no sign of fecal pellet size limitation in either pallium-feeders or peduncle-feeders, the smallest species that fed using direct engulfment (Gyrodinium dominans) could not engulf intact Acartia tonsa fecal pellets, relying instead on fragments, indicating that this species mainly ingests pellets $\leq 40 \mu \mathrm{m}$.

\section{Feeding behavior and important factors for pellet grazing by dinoflagellates}

The investigated dinoflagellate species did not respond in the same way to the pellets although all of the species were able to detect the chemical cue leaking from the pellet. Diplopsalis lenticula, Gyrodinium dominans, Gyrodinium spirale, Karlodinium armiger, the gymnodinoid dinoflagellate (Gy1), and Protoperidinium depressum were attracted by the cue and were all observed to feed on the pellets or attempt feeding (Gy1) (Table 4). Although Dinophysis acuminata reacted to the chemical cue from Rhodomonas salina-based fecal pellets, no feeding response could be detected towards the pellet. This may be due to a number of factors. Dinophysis does not feed on $R$. salina, and this likely explains the lack of a feeding response to $R$. salina-based fecal pellets. All cultures of photosynthetic Dinophysis acuminata (as well as other species of Dinophysis) have so far 
been kept on the photosynthetic ciliate Mesodinium rubrum as prey (e.g. Park et al. 2006, Riisgaard \& Hansen 2009). To what extent $D$. acuminata relies on other food organisms is unknown at present. Thus, we cannot exclude that this species feeds on fecal pellets produced by copepods feeding on other organisms that better match the food preferences of this species (i.e. M. rubrum-based pellets).

Pellet age was important for the feeding response of the dinoflagellates towards pellets. The chemical cue from a pellet weakens with time (age), as the limited content of dissolved organic matter (DOM) rapidly diffuses from the pellet and is diluted by the surrounding water. In addition, bacterial degradation modifies the cue. Copepod fecal pellets rapidly leak DOM (Møller et al. 2003, Thor et al. 2003), with a large part of the DOM content being released or leaked within the first 5 min of egestion (Jumars et al. 1989). Rapid leakage of DOM from the pellets was also indicated in this study, where detection distance reached its maximum within 6 to 10 min of the start of the experiment. The signal from the pellet is therefore strongest and can be detected at maximum distance within 10 to 15 min of egestion. Old pellets (50 min to $2 \mathrm{~d}$ old, handling time + recording time) induced fewer feeding attempts than fresh pellets for all pellet-feeding dinoflagellates, indicating selection for the freshest pellets of higher food quality. In addition, the chemical cue from fresh pellets more closely resembles the signal from the live algal food source compared to older pellets. The majority of the pellets offered in the grazing experiments were $>1 \mathrm{hr}$ old at the start of incubation ( $20 \mathrm{~min}$ to $20 \mathrm{~h}$ ) and, likely, did not induce a feeding response in the dinoflagellate species investigated in this study. It follows that the clearance-, ingestion- and degradation rates obtained in this study must be underestimated, compared to grazing in the field where fresh pellets are produced continuously. Pellet age, and thus the composition and strength of the chemical cue, is therefore an important factor for pellet feeding behavior in dinoflagellates.

\section{Importance of dinoflagellate grazing on copepod fecal pellets}

Although we observed feeding in 6 out of the 7 dinoflagellate species tested, we were only able to get significant grazing rates from Gyrodinium spirale and Protoperidinium depressum. The main reason for this is, of course, the selected dinoflagellate concentrations as well as pellet concentrations. We deliberately chose dinoflagellate and pellet concentrations of each species that were within the range found in nature. The observed clearance rates for fecal pellets based on Rhodomonas salina were $0.21 \pm 0.04$ and $0.32 \pm 0.12 \mathrm{ml} \mathrm{cell}^{-1} \mathrm{~d}^{-1}$ (average \pm SE) for $G$. spirale and $P$. depressum, respectively. A field experiment, with pellets of the same type, and produced with the same method as in this study recorded a clearance rate of $G$. spirale of the same magnitude $\left(0.95 \mathrm{ml} \mathrm{cell}^{-1} \mathrm{~d}^{-1}\right)$ as that observed here (Poulsen \& Iversen 2008). However, our clearance rates are much higher than previously measured in the laboratory with the dinoflagellate Heterocapsa triquetra as prey $\left(0.007 \mathrm{ml} \mathrm{cell}^{-1} \mathrm{~d}^{-1}\right.$, Hansen 1992). No grazing data are available for $P$. depressum from either laboratory or field experiments. However, reported clearance rates of other pallium-feeding dinoflagellates (i.e. Protoperidinium spp. and Diplopsalis lenticula) lie in the range of 0.011 to $0.065 \mathrm{ml} \mathrm{cell}{ }^{-1} \mathrm{~d}^{-1}$ (Jacobson \& Anderson 1993, Jeong \& Latz 1994, Naustvoll 1998). Thus, the measured clearance of $P$. depressum on copepod fecal pellets is comparatively high. These discrepancies between clearance rates on fecal pellets compared to clearance rates on other algae are probably due to several things. The low clearance rates of G. spirale on $H$. triquetra is likely due to high prey concentrations used in these experiments and the fact that $H$. triquetra is a suboptimally sized prey (equivalent spherical diameter $[\mathrm{ESD}]=15.8 \mu \mathrm{m})$. Apart from size, chemical detection of prey particles may also play an important role. Freshly produced fecal pellets are large particles, densely packed with more or less degraded algal material and a larger content of DOM compared to smaller algae. The chemical signal from fresh pellets is therefore stronger and can be detected at greater distances from the pellet than a single, live algal cell.

The small Gyrodinium dominans (20 to $30 \mu \mathrm{m}$ cell length) was able to detect a pellet at maximum distances of $366 \pm 33 \mu \mathrm{m}$, which is 13 times its cell length. The detection distances measured in this study are not representative of those found in the field, but demonstrate the response of dinoflagellates to the cue leaking from the pellet. A pellet lying on the bottom of a Petri dish in a laboratory study emits a dome shaped chemical cue, whereas a sinking pellet in the field emits a flame shaped trail (Kiørboe \& Thygesen 2001, Kiørboe \& Jackson 2001). In conclusion, the high pellet clearance rates of $G$. spirale and Protoperidinium depressum compared to clearance rates from other laboratory studies may be explained by the large size of the pellets, the strong chemical 
signal released by the pellet, by the higher prey concentrations used in other studies, and perhaps by suboptimal prey items.

Fecal pellet degradation rates obtained in this study were high and within the range found in field studies for similar pellets (Poulsen \& Iversen 2008), and for in situ pellets (Poulsen \& Kiørboe 2006). Natural cell concentrations of heterotrophic dinoflagellates $(>20 \mu \mathrm{m})$ may be as high as 25 cells ml$^{-1}$ during blooms in coastal, temperate waters (Hansen 1991, P. J. Hansen unpubl. data). Thus, with clearance rates of about 0.2 to $0.3 \mathrm{ml} \mathrm{cell}^{-1} \mathrm{~d}^{-1}$, pellet removal rates by heterotrophic dinoflagellates may in principle be as high as 1.5 and $7.5 \mathrm{~d}^{-1}$. This is in accordance with reported maximum pellet degradation rates of 2.5 to $13 \mathrm{~d}^{-1}$ from field studies (Kiørboe 2003, Poulsen \& Kiørboe 2006, Poulsen \& Iversen 2008). Pellet degradation rates in these field studies were indicated to be caused mainly by protozooplankton or organisms $<200 \mu \mathrm{m}$. In the field mainly small to medium sized pellets $(\leq 300 \mu \mathrm{m}$ in length) are degraded within the water column (Turner 2002, Poulsen \& Kiørboe 2006). Pellets of this size generally sink at rates of $<100 \mathrm{~m}$ $\mathrm{d}^{-1}$ and Acartia tonsa pellets sink at rates of 2 to $84 \mathrm{~m}$ $\mathrm{d}^{-1}$ (Poulsen \& Kiørboe 2006, Ploug et al. 2008). These sinking rates correspond to reported swimming rates for both heterotrophic and mixotrophic dinoflagellates (4 to $138 \mathrm{~m} \mathrm{~d}^{-1}$, Kamykowski \& McCollum 1986, Levandowsky \& Kaneta 1987, Buskey 1997). Dinoflagellates are therefore able to encounter, capture and degrade small to medium sized fecal pellets but are, likely, limited by the size and sinking rates of very large copepod fecal pellets (sizes $>400 \mu \mathrm{m}$, sinking rates $>100 \mathrm{~m} \mathrm{~d}^{-1}$ ). In conclusion, this study shows that heterotrophic dinoflagellates alone can account for observed pellet degradation rates in field studies. This is despite the fact that the grazing rates presented here are underestimated, due to the suboptimal age of the pellets offered in the grazing experiments. However, further investigation is needed.

In this study, growth was observed for Gyrodinium spirale and Karlodinium armiger feeding on Rhodomonas salina-based fecal pellets, and Protoperidinium depressum was able to maintain its metabolism on both $R$. salina and Ditylum brightwelliibased pellets. $G$. spirale growth rates $\left(0.69 \mathrm{~d}^{-1}\right)$ were equal to or higher than those found on live algae (0.53 to $0.79 \mathrm{~d}^{-1}$, Hansen 1992, Kim \& Jeong 2004). The growth rate of $P$. depressum $\left(0.08 \mathrm{~d}^{-1}\right)$ feeding on $R$. salina fecal pellets was low compared to maximum growth rates for this species feeding on live algal food sources (0.72 to 1.23, Buskey et al. 1994; $0.21 \mathrm{~d}^{-1}$, Menden-Deuer et al. 2005). This demon- strates that dinoflagellates can obtain growth from copepod fecal pellets. The measured ingestion rates were in the range of 0.1 to 0.2 pellets dinoflagellate ${ }^{-1}$ $\mathrm{d}^{-1}$ at a pellet concentration of between 0.4 and 1.5 pellets $\mathrm{ml}^{-1}$. This is equivalent to ingestion rates of $\sim 1.2$ to $2 \times 10^{4} \mu^{3}$ cell $^{-1} \mathrm{~d}^{-1}$ (Table 6). Assuming cell volumes of $1 \times 10^{4} \mu^{3}$ for G. spirale and $1 \times 10^{5}$ $\mu^{3}{ }^{3}$ for $P$. depressum (P. J. Hansen unpubl. data), the calculated growth yield (defined as: $\mu \times$ cell volume/ ingested volume) would be 0.58 and 0.50 , respectively. Such growth yields are within the range found for heterotrophic dinoflagellates fed live algae (Hansen et al. 1997). This indicates that the fecal pellets were of a high nutritional value and, furthermore, that the low growth rate of $P$. depressum on copepod pellets was most likely caused by a suboptimal pellet concentration in the grazing experiment.

This study also documented that mixotrophic dinoflagellates (i.e. Karlodinium armiger) have the ability to feed and grow on copepod fecal pellets. In our grazing and growth experiments, we used relatively low cell concentrations (100 to 400 cells ml ${ }^{-1}$ ), and we therefore did not get significant grazing rates on fecal pellets in the grazing experiment. However, in the behavior study most of the pellet was removed within $48 \mathrm{~h}$ at concentrations of 3400 to 4700 cells $\mathrm{ml}^{-1}$. Thus, the concentration of small dinoflagellates has to be high in nature (e.g. blooms) to significantly impact pellet degradation rate within the water column, although this is of course also dependent on pellet size. Medium sized Acartia tonsa pellets were used in this study. This suggests that large phagotrophic dinoflagellates $(>20 \mu \mathrm{m})$ are the main degraders of copepod fecal pellets (Poulsen \& Iversen 2008). More research is required to explore and assess the importance of heterotrophic and mixotrophic dinoflagellates as degraders of copepod fecal pellets.

The ability of large heterotrophic dinoflagellates to supplement their diet with copepod fecal pellets gives these protists an added advantage when phytoplankton-prey is heterogeneous in time or space or the size composition is unsuitable. Pellet feeding could explain the observation of co-occurrence of large $(>20 \mu \mathrm{m})$ heterotrophic dinoflagellates in offshore tropical waters dominated by very small algae (in the pico fraction), which are unsuitable food items for these dinoflagellates (Nielsen et al. 2004). Pellet feeding by dinoflagellates is, however, not limited to periods of prey limitation. Protozooplankton were observed to be the key degraders of pellets throughout the year, in a study of pellet degradation by an in situ plankton community, and maximum degradation 
rates were found during the spring bloom with the abundance of Gyrodinium spirale as a good predictor for the pellet degradation rate (Poulsen \& Iversen 2008). Pellet feeding is, therefore, a feeding behavior determined by the suitability of the chemical cue leaking from the pellet, and not the abundance of alternative phytoplankton prey. Co-occurring dinoflagellate and copepod communities in the field graze on the same plankton organisms, due to the ability of dinoflagellates to graze particles at high prey-to-dinoflagellate size ratios (Jacobson \& Anderson 1986, Hansen et al. 1994, Hansen \& Calado 1999, Berge et al. 2008). The fresh pellets encountered by a dinoflagellate in the field are therefore likely based on algae with a chemical cue, which induces a feeding response in the dinoflagellate. Thus, heterotrophic and mixotrophic dinoflagellates, which do not avoid the pellets, likely react to the chemical cue as with any other acceptable food source. A limiting factor for the response and grazing rates of the dinoflagellates may be the degree of digestion of the pellet by the copepod, which varies with food concentration and food source. Further investigation is needed to clarify this. icant degradation rates of copepod fecal pellets, (5) avoidance behavior; dinoflagellates that respond to the chemical signal with avoidance will not impact pellet degradation significantly (Gy1). In the field the abundance of large $(>20 \mu \mathrm{m})$ dinoflagellates and the dinoflagellate-to-pellet size ratio will determine the grazing impact of dinoflagellates on copepod fecal pellets. Pellet age and pellet food source should not be a major problem, since the copepod community continuously produces fresh fecal pellets on the same plankton community that the dinoflagellates prey on. These results are based on laboratory studies and therefore more studies are needed to fully understand the determining factors for pellet degradation by dinoflagellates in the field.

Acknowledgements. We thank U. Tillmann for providing us with the Diplopsalis lenticula culture and for valuable comments on the draft manuscript. We are also indebted to $\mathrm{M}$. Ellegaard, E. Warrant and 3 anonymous reviewers for significantly improving the manuscript. L.K.P. was supported by The Carlsberg Foundation (2007_01_0495). M.M. and T.B. were supported by $\mathrm{PhD}$ grants from the Faculty of Science, University of Copenhagen. P.J.H. was supported by grant no 272-06-0485.

\section{CONCLUSIONS}

\section{LITERATURE CITED}

This study reveals a new trophic role for dinoflagellates as detritivores, and shows that large $(>20 \mu \mathrm{m})$ heterotrophic dinoflagellates alone can account for reported pellet degradation rates in field studies. The enigma of the rapidly disappearing pellets within the upper part of the water column can therefore be explained by dinoflagellate grazing, confirming that dinoflagellates can function as an effective 'protozoan filter' for fecal pellets in the water column (Poulsen \& Iversen 2008).

Important factors for copepod fecal pellet grazing by dinoflagellates are: (1) food source of the pellet; the food source must induce a feeding response in the dinoflagellates, (2) pellet age; old pellets (50 min to $2 \mathrm{~d}$ old) induced fewer feeding attempts than fresh pellets for all pellet feeding dinoflagellates, (3) the dinoflagellate-to-pellet size ratio in combination with the feeding mechanism employed by the dinoflagellate species; no sign of food particle size limitation was observed for either pallium-feeders or pedunclefeeders, however, direct-engulfment feeders were limited by their size and fed mainly on pellets $<6$ times their own size (length), (4) dinoflagellate abundance; small dinoflagellates $(<20 \mu \mathrm{m})$ in particular have to be in high numbers (blooms) to obtain signif-

Azam F, Fenchel T, Field JS, Gray JS, Mevel-Reil LA, Thingstad F (1983) The ecological role of water-column microbes in the sea. Mar Ecol Prog Ser 10:257-263

$>$ Berge T, Hansen PJ, Moestrup Ø (2008) Feeding mechanism, prey specificity and growth in light and dark of the plastidic dinoflagellate Karlodinium armiger. Aquat Microb Ecol 50:279-288

Breckels MN, Roberts EC, Archer SD, Malin G, Steinke M (2011) The role of dissolved infochemicals in mediating predator-prey interactions in the heterotrophic dinoflagellate Oxyrrhis marina. J Plankton Res 33(4):629-639

> Buskey EJ (1997) Behavioral components of feeding selectivity of the heterotrophic dinoflagellate Protoperidinium pellucidum. Mar Ecol Prog Ser 153:77-89

Buskey EJ, Coulter CJ, Brown SL (1994) Feeding, growth and bioluminescence of the heterotrophic dinoflagellate Protoperidinium huberi. Mar Biol 121:373-380

Calado AJ, Moestrup O (1997) Feeding in Peridiniopsis berolinensis (Dinophyceae): New observations on tube feeding by an omnivorous, heterotrophic dinoflagellate. Phycologia 36:47-59

> Dubischar CD, Bathmann UV (2002) The occurrence of faecal material in relation to different pelagic systems in the Southern Ocean and its importance for vertical flux. Deep-Sea Res II 49:3229-3242

> Gribble KE, Nolan G, Anderson DM (2007) Biodiversity, biogeography and potential trophic impact of Protoperidinium spp. (Dinophyceae) off the southwestern coast of Ireland. J Plankton Res 29:931-947

Guillard RRL (1975) Culture of phytoplankton for feeding marine invertebrates. In: Smith WL, Chanley MH (eds) 
Culture of marine invertebrate animals. Plenum Press, New York, NY, p 29-60

- Hansen PJ (1991) Quantitative importance and trophic role of heterotrophic dinoflagellates in a coastal pelagial food web. Mar Ecol Prog Ser 73:253-261

Hansen PJ (1992) Particle selection, feeding rates and growth dynamics of marine heterotrophic dinoflagellates with special emphasis on Gyrodinium spirale. Mar Biol 114:327-334

- Hansen PJ, Calado A (1999) Phagotrophic mechanisms and prey selection in free-living dinoflagellates. J Eukaryot Microbiol 46:382-389

> Hansen PJ, Hansen B, Bjørnsen PK (1997) Zooplankton grazing and growth: scaling within the size range $2 \mu \mathrm{m}$ to $2000 \mu \mathrm{m}$. Limnol Oceanogr 42:687-704

> Hansen B, Bjørnsen PK, Hansen PJ (1994) Prey size selection in planktonic zooplankton. Limnol Oceanogr 39:395-403

$>$ Hansen B, Fotel FL, Jensen NJ, Madsen SD (1996) Bacteria associated with a marine planktonic copepod in culture. II. Degradation of fecal pellets produced on a diatom, a nanoflagellate or a dinoflagellate diet. J Plankton Res 18: 275-288

> Humes AG (1994) How many copepods? Hydrobiologia 292-293:1-7

> Jacobson DM, Anderson DM (1986) The thecate dinoflagellates-feeding behavior and mechanisms. J Phycol 22: 249-250

$>$ Jacobson DM, Anderson DM (1993) Growth and grazing rates of Protoperidinium hirobis Abe, a thecate heterotrophic dinoflagellate. J Plankton Res 15:723-736

> Jakobsen HH, Hansen PJ (1997) Prey size selection, grazing and growth response of the small heterotrophic dinoflagellate Gymnodinium sp. and the ciliate Balanion comatum-a comparative study. Mar Ecol Prog Ser 158:75-86

> Jakobsen HH, Everett LM, Strom SL (2006) Hydromechanical signaling between the ciliate Mesodinium pulex and motile protest prey. Aquat Microb Ecol 44:197-206

Jennings HS (1906) Behavior of lower organisms. Columbia University Press, New York, NY

$>$ Jeong HJ (1994) Predation by the heterotrophic dinoflagellate Protoperidinium cf. divergens on copepod eggs and early naupliar stages. Mar Ecol Prog Ser 114:203-208

$>$ Jeong HJ (1999) The ecological role of heterotrophic dinoflagellates in marine planktonic community. J Eukaryot Microbiol 46:390-396

> Jeong HJ, Latz MI (1994) Growth and grazing rates of the heterotrophic dinoflagellates Protoperidinium spp on red tide dinoflagellates. Mar Ecol Prog Ser 106:173-185

Jumars PA, Penry DL, Baross JA, Perry MJ, Frost BW (1989) Closing the microbial loop: dissolved carbon pathway to heterotrophic bacteria from incomplete ingestion, digestion and absorption in animals. Deep-Sea Res 36:483-495

Kamykowski D, McCollum SA (1986) The temperature acclimated swimming speed of selected marine dinoflagellates. J Plankton Res 8:275-287

> Kim JS, Jeong HJ (2004) Feeding by the heterotrophic dinoflagellate Gyrodinium dominans and $G$. spirale on the red-tide dinoflagellate Prorocentrum minimum. Mar Ecol Prog Ser 280:85-94

Kimor B (1979) Predation by Noctiluca miliaris Souriray on Acartia tonsa Dana eggs in inshore waters of southern California. Limnol Oceanogr 24:568-572

Kiørboe T (2003) High turnover rates of copepod fecal pellets due to Noctiluca scintillans grazing. Mar Ecol Prog Ser 258:181-188
Kiørboe T, Jackson GA (2001) Marine snow, organic solute plumes, and optimal chemosensory behavior of bacteria. Limnol Oceanogr 46:1309-1318

Kiørboe T, Thygesen UH (2001) Fluid motion and solute distribution around sinking aggregates. II. Implications for remote detection by colonizing zooplankters. Mar Ecol Prog Ser 211:15-25

Kiørboe T, Möhlenberg F, Riisgaard HU (1985) Bioenergetics of the planktonic copepod Acartia tonsa: Relation between feeding, egg production and respiration, and composition of specific dynamic action. Mar Ecol Prog Ser 26:85-97

Komar PD, Morse AP, Small LF, Fowler SW (1981) An analysis of sinking rates of natural copepod and euphausiid fecal pellets. Limnol Oceanogr 26:172-180

Levandowsky M, Kaneta P (1987) Behavior in dinoflagellates. In: Taylor FJR (ed) The biology of dinoflagellates. Bot Monogr 21, Blackwell, p 360-398

Mauchline J (1998) The biology of calanoid copepods. In: Blaxter JHS, Southward AJ, Tyler PE (eds) Adv Mar Biol 33. Academic Press, London

> Menden-Deuer S, Lessard EJ, Satterberg J, Grunbaum D (2005) Growth rates and starvation survival of three species of the pallium-feeding, thecate dinoflagellate genus Protoperidinium. Aquat Microb Ecol 41:145-152

Møller EF, Thor P, Nielsen TG (2003) Production of DOC by Calanus finmarchicus, C. glacialis and C. hyperboreus through sloppy feeding and leakage from fecal pellets. Mar Ecol Prog Ser 262:185-191

> Naustvoll LJ (1998) Growth and grazing by the thecate heterotrophic dinoflagellate Diplopsalis lenticula (Diplopsalidaceae, Dinophyceae). Phycologia 37:1-9

> Nielsen TG, Bjørnsen PK, Boonruang P, Fryd M and others (2004) Hydrography, bacteria and protist communities across the continental shelf and shelf slope of the Andaman Sea (NE Indian Ocean). Mar Ecol Prog Ser 274:69-86

Park MG, Kim S, Kim HS, Myung G, Kang YG, Yih W (2006) First successful culture of the marine dinoflagellate Dinophysis acuminata. Aquat Microb Ecol 45:101-106

Ploug H, Iversen MV, Koski M, Buitenhuis ET (2008) Production, oxygen respiration rates and sinking velocity of copepod fecal pellets: Direct measurements of ballasting by opal and calcite. Limnol Oceanogr 53: 469-476

Poulsen LK, Iversen MH (2008) Degradation of copepod fecal pellets: key role of protozooplankton. Mar Ecol Prog Ser 367:1-13

Poulsen LK, Kiørboe T (2006) Vertical flux and degradation rates of copepod fecal pellets in a zooplankton community dominated by small copepods. Mar Ecol Prog Ser 323:195-204

Riisgaard K, Hansen PJ (2009) Role of food uptake for photosynthesis, growth and survival of the mixotrophic dinoflagellate Dinophysis acuminata. Mar Ecol Prog Ser 381: 51-62

Schnepf E, Drebes G (1986) Chemotaxis and appetence of Paulsenella sp. (Dinophyta) an ectoparasite of the marine diatom Streptotheca thamesis Shrubsole. Planta 167: 337-343

Spero HJ (1985) Chemosensory capabilities in the phagotrophic dinoflagellate Gymnodinium fungiforme. J Phycol 21:181-184

Tamar H (1965) The culture, structure, and locomotion of Halteria grandinella. Acta Protozool 3:165-172 
Thor P, Dam HG, Rogers DR (2003) Fate of organic carbon released from decomposing copepod fecal pellets in relation to bacterial production and ectoenzymatic activity. Aquat Microb Ecol 33:279-288

> Turner JT (2002) Zooplankton fecal pellets, marine snow and sinking phytoplankton blooms. Aquat Microb Ecol $27: 57-102$

Editorial responsibility: Edward Durbin, Narragansett, Rhode Island, USA
Vogelbein WK, Lovko VJ, Shields JD, Reece KS, Mason PL, Haas LW, Walker CC (2002) Pfiesteria shumwayae kills fish by micropredation not exotoxin secretion. Nature 418:967-970

Wotton RS (1994) Particulate and dissolved organic matter as food. In: Wotton RS (ed) The biology of particles in aquatic systems. Lewis, Boca Raton, FL

Submitted: November 11, 2010; Accepted: August 19, 2011 Proofs received from author(s): October 28, 2011 